Selcuk Journal of Agriculture and Food Sciences

http://sjafs.selcuk.edu.tr/sjafs/index

Research Article

\section{SJAFS}

(2019) 33 (1), 42-44

e-ISSN: 2458-8377

DOI:10.15316/SJAFS.2019.154

\title{
A Study on Relationships between Various Quantitative Characteristics for Using Availability Quantitative Trait Loci Mapping*"
}

\author{
Özge ŞAHİN ${ }^{1, *}$, Orhan KAVUNCU ${ }^{2}$ \\ ${ }^{1}$ Institute for Evolution and Biodiversity, Faculty of Biology, University of Münster, Hüfferstrasse 1, Müster, Germany \\ ${ }^{2}$ Department of Genetics and Bioengineering, Faculty of Engineering and Architecture, Kastamonu University,
} Kastamonu, Turkey

\begin{tabular}{l}
\hline ARTICLE INFO \\
\hline Article history: \\
Received date: 03.01 .2019 \\
Accepted date: 05.04 .2019 \\
\hline
\end{tabular}

Edited by:

İbrahim AYTEKIN; Selçuk University, Turkey

\section{Reviewed by:}

Yasemin GEDIK; Ankara University, Turkey

Mehmet Cengiz BALOĞLU;

Kastamonu University, Turkey

\section{Keywords:}

Flour Beetle

QTL

Pupa Weight

\section{Introduction}

Many features are controlled by multiple genes and environmental factors. Although these features are very simple as phenotypes, they are complex as genotypes. It is therefore also often referred to as complex features (Lander and Kruglyak, 1995). These complex features are often quantitative traits. Quantitative traits are features which have continuous distri ${ }^{1}$ butions on phenotypes. The variations of these traits are controlled by segregation of many loci, and therefore they are studied via more complex methods because of segregation of a lot of loci. The concepts of the linkage between genes and marker loci have given rise to the term quantitative trait locus (Tanksley, 1993). Quantitative trait loci (QTL) can be a major gene or a small set of small genes that have effects on the phenotype together.

\footnotetext{
*Corresponding author email: sahino@uni-muenster.de ** This study was conducted as an MSc thesis (Şahin, 2016) in Ankara University Faculty of Agriculture, Department of Animal Science.

Short communication
}

Utilization of the linked genes in indirect selection for any quantitative trait had been taken into account long before (Düzgüneş and Ekingen, 1983). Separation of each major gene and information about QTL presence by using the correlation of the quantitative phenotype with a single marker locus or a set of marker loci can potentially find many useful applications. For instance, the information on the QTL presence can be used to improve the effect of selective breeding for characteristics that can be observed in a single gender with lower heritability. Another important potential is that it can be applied transgenic technology for quantitative traits. It is known that identification of alleles predisposing to common multifactorial diseases such as heart disease or diabetes can help in the development of methods of preventing these diseases (Falconer and Mackay, 1996).

The study of genetic constructs of quantitative traits using molecular markers implies QTL mapping, in fact, by making use of the relationship between marker loci and quantitative traits (Xu, 2002). Many properties with economic and medical prescription in humans, animals or plants are polygenic. The presence of high amounts of polymorphic DNA markers in many species allows for the preparation of genetic maps well and the examination of genetic structures of 
complex quantitative traits. Systematic screening of the entire genome for QTL by the use of molecularlinkage maps may account for a large portion of the total phenotypic variance (Zhong \& Yan, 2003).

In this study, we have tried to review the QTL methods used in the literature and wanted to apply them in an example material to conceive the subject. So, the Tribolium confusum Jacquelin du Val, 1868 (Coleoptera: Tenebrionidae) was preferred just as an example and a model organism because its generation interval is very short and easy to measure the pupae weight. On the other hand, this model organism is a well-known pest for stored products. Therefore having more information about its genetic structure is very useful for future research studies.

The life cycle of Tribolium has four main stages including egg, larva, pupa and adult. The eggs are quite small, white and flexible. The larvae hatch out after 1-2 days in appropriate circumstances. After changing of six shirts, the larvae enter the pupal stage at $19^{\text {th }}-21^{\text {st }}$ day. The pupal stage lasts 3-4 days. After pupal stage, adults access sexual maturity and reproductive capacity in 3-5 days. Adult beetles live for 1-2 years and can produce around 15 eggs each female per day at the appropriate conditions (Sokoloff, 1977).

\section{Materials and Methods}

\section{1. Tribolium confusum (Coleoptera: Tenebrionidae) and preparation of medium}

Tribolium species are insects belonging to $\mathrm{Te}$ nebrionidae family of Coleoptera order and have many detrimental effects to food such as stored flour, semolina, chocolate, spices, and dried fruit. They can eat almost every type of stored food (Tribolium Genome Sequencing Consortium, 2008). In addition to this, some of them can have a flight capability and be found far from storage locations (Semeao et al., 2010).

There are several reasons for studying Tribolium species. One of the most important reason is that Tribolium is a model organism for classic genetic studies. It is also the only genetic model for medically and agriculturally significant coleopteran species (Brown et al., 2003).

In the study, $T$. confusum lines which were brought to Population Genetics Laboratory in Ankara Univer- sity Faculty of Agriculture, Department of Biometry and Genetics in 1993 were used as live material in 2016. These beetles were held in the medium consisting of $95 \%$ flour and $5 \%$ yeast mixture which were placed in the incubators adjusted to suitable moisture and $32.5^{\circ} \mathrm{C}$ temperature.

\subsection{Mating}

Two of these $T$. confusum lines were selected randomly. They were named as Tcf 181 NewYork and Tcf 117. Firstly, 25 females of Tcf 181 NewYork line and 25 males of Tcf 117 were selected randomly and their $21^{\text {st }}$ day pupal weight was measured. The difference between the means of the lines was found to be insignificant. Although this situation, hybridizations were continued with the idea of finding a variation due to non-additive effects between and within QTL. According to this opinion, 40 numbers of $F_{1}$ progenies' pupal weight and 20 numbers of $F_{2}$ progenies' pupal weight were measured. Then, 20 numbers of $F_{1}$ progenies were selected randomly and were separated as 10 females and 10 males to hybridize with $T c f 181$ NewYork. Reciprocal backcrosses were carried out.

\subsection{DNA isolation and PCR}

For isolation of the genomic DNA, the DNA isolation protocol reported by Hall (1986, 1990) was adapted to the laboratory conditions. After DNA isolation, different genotypes between ancestral lines were seen at AC154135 marker locus obtained from the NCBI GenBank database.

This marker locus was amplified by using the report which William et al reported in 1990. This report was adapted the laboratory conditions and 5, GTAGACCCGT 3' was used as primer. According to this report PCR conditions included 45 cycles of denaturation at $94^{\circ} \mathrm{C}$ for $1 \mathrm{~min}$, annealing at $36^{\circ} \mathrm{C}$ for $1 \mathrm{~min}$ and extension at $72^{\circ} \mathrm{C}$ for $2 \mathrm{~min}$. It was also included pre-denaturation at $94^{\circ} \mathrm{C}$ for $2 \mathrm{~min}$ and last extension at $72^{\circ} \mathrm{C}$ for $10 \mathrm{~min}$.

\section{Results and Discussion}

At the beginning of the study, selected $T$. confusum lines' descriptive statistics on pupal weight were calculated. These descriptive statistics are shown in Table 1 .

Table 1

Descriptive statistics of Tcf 181 New York and Tcf 117 on $21^{\text {st }}$ day pupal weight $(\mathrm{g})$

\begin{tabular}{llcccccc}
\hline Variation & $\mathrm{N}$ & Mean & SE of the Mean & Std Dev & Variance & Minimum & Maximum \\
\hline Tcf 181 & 25 & 2.44 & 0.07 & 0.35 & 0.12 & 1.89 & 3.07 \\
Tcf 117 & 25 & 2.39 & 0.06 & 0.32 & 0.10 & 1.87 & 3.02 \\
\hline
\end{tabular}

There was not found any significant difference between the means of $21^{\text {st }}$ day pupal weights of the lines. In this case, a QTL research and mapping study between these two lines which have different genotypes at marker loci, but have not any significant difference on pupal weight was unable to do. However, with the hope that there is a possibility of non-additive effects and in terms of being a practice on the implementation of the method the planned further hybridizations and analysis were performed.

Some of the descriptive statistics of the lines which were used for mating and their offspring were showed on Table 2. 
Table 2

Descriptive statistics of the lines on $21^{\text {st }}$ day pupal weight

\begin{tabular}{ccccccc}
\hline Variation & \multirow{2}{*}{$T c f 181 \mathrm{NY}$} & Tcf 117 & $\mathrm{~F}_{1}$ & $\mathrm{~F}_{2}$ & $\begin{array}{c}\text { Tcf 181 NY (Female)/ } \\
\mathrm{F}_{1}(\text { Male })\end{array}$ & $\begin{array}{c}\text { Tcf 181 NY (Male)/ } \\
\mathrm{F}_{1}(\text { Female) }\end{array}$ \\
\hline $\mathrm{N}$ & 25 & 25 & 40 & 20 & 10 & 10 \\
$\bar{X}$ & 2.44 & 2.39 & 2.27 & 2.43 & 2.35 & 2.24 \\
$S_{\bar{X}}$ & 0.07 & 0.06 & 0.05 & 0.07 & 0.09 & 0.09 \\
$S_{X}$ & 0.35 & 0.32 & 0.34 & 0.33 & 0.28 & 0.25 \\
$\mathrm{~S}$ & 0.12 & 0.10 & 0.12 & 0.11 & 0.09 & 0.06 \\
\hline Minimum & 1.89 & 1.87 & 1.54 & 1.85 & 1.92 & 1.82 \\
Maximum & 3.07 & 3.02 & 2.95 & 2.92 & 2.87 & 2.65 \\
\hline
\end{tabular}

The differences between the means of pupal weights were examined with ANOVA in Minitab 16 statistical software package. The analysis was done to check out if there is a difference between the means of pupal weight on the generations which were included in the study. The results of variance analysis are shown in Table 3.

Table 3

Variance analysis

\begin{tabular}{lccccc}
\hline Source & DF & SS & MS & F & P \\
\hline Factor & 5 & 0.7075 & 0.1415 & 1.32 & 0.258 \\
Error & 124 & 13.2491 & 0.1068 & & \\
Total & 129 & 13.9566 & & & \\
\hline
\end{tabular}

There was not any significant difference between the groups in terms of mean pupal weight at the results of this variance analysis. In this case, it can be concluded that there is not a genetic variation present material obtained in terms of pupa weight. Therefore, it was decided that this situation was not suitable for studying QTL.

Consequently, in terms of quantitative aspects the lines to be crossed had to have phenotypic differences or at least $F_{1}$ had to be a significant difference from the parent lines. If these differences were observed, it could be examined quantity of the genotypic difference on the phenotypic difference and the places of these genes could be detected on the genome.

\section{References}

Brown SJ, Denell RE, Beeman RW (2003). Beetling around the genome. Genetics Research Cambridge 82 (3): 155-161.

Düzgüneş O, Ekingen HR (1983). Genetics. Faculty of Agriculture Publications of Ankara University, Ankara, 343 pp.

Falconer DS, Mackay TFC (1996). Introduction to Quantitative Genetics (Fourth Edition). Addison Wesley Longman Limited, Harlow, Essex, 464 pp.

Hall HG (1986). DNA differences found between Africanized and European honeybees. Proceedings of the National Academy of Sciences of the United States of America 83 (13): 4874-4877.
Hall HG (1990). Parental analysis of intogressive hybridization between African and European honeybees using nuclear DNA RFLPs. Genetics 125: 611-621.

Lander E, Kruglyak L (1995). Genetic dissection of complex traits: guidelines for interpreting and reporting linkage results. Nature Genetics 11: 241247.

Semeao AA, Campbell JF, Beeman RW, Whitworth RJ, Sloderbeck PE, Lorenzen MD (2010). Genetic structure of Tribolium castaneum populations in mills. Julius-Kühn-Archiv 425: 85-89.

Sokoloff A (1977). The Biology of Tribolium: with Special Emphasis on Genetic Aspects. Clarendon Press, Oxford, 628 pp.

Şahin Ö (2016). Tribolium confusum'da çeşitli özellikler arasındaki ilişkilerin QTL haritalamada kullanılabilirliği üzerine bir araştırma. Yüksek Lisans Tezi, Ankara Üniversitesi Fen Bilimleri Enstitüsü, Ankara, Türkiye.

Tanksley SD (1993). Mapping polygenes. Annual Review of Genetics 27: 205-233.

Tribolium Genome Sequencing Consortium (2008). The genome of the model beetle and pest Tribolium castaneum. Nature 452 (7190): 949-955.

Williams JGK, Kubelik AR, Livak KJ, Rafalski JA, Tingey SF (1990). DNA polymorphism amplified by arbitrary primers are useful as genetic markers. Nucleic Acids Research 18 (22): 6531-6535.

Xu S (2002). QTL Analysis in Plants. In Camp NJ \& Cox A (Eds) Quantitative Trait Loci: Methods and Protocols. Humana Press, Totowa, New Jersey, 376 pp.

Zhong D, Pai A, Yan G (2003). Quantitative trait loci for susceptibility to tapeworm infection in the red flour beetle. Genetics 165 (3): 1307-1315. 